\title{
FAKTOR-FAKTOR YANG MEMPENGARUHI EKSPOR KOPI DI ACEH
}

(Factors Affecting Coffee Exports in Aceh)

\author{
Mardhiah $^{1}$, Akhmad Baihaqi, Safrida ${ }^{1 *}$ \\ ${ }^{1}$ Program Studi Agribinis, Fakultas Pertanian, Universitas Syiah Kuala \\ *Corresponding author: safrida@unsyiah.ac.id
}

\begin{abstract}
Abstrak. Penelitian ini bertujuan untuk melihat faktor-faktor yang mempengaruhi ekspor kopi di Aceh. Sumber data yang digunakan adalah data sekunder yang berupa time series dari tahun 2001 - 2017. Model analisis yang digunakan adalah regresi linear berganda, uji $F$, uji $t$ dan uji $R^{2}$. Hasil analisis regresi diperoleh $Y=-9,365-2,825_{\mathrm{NT}}+2,616_{\mathrm{HKDN}}-$ $1,734_{\mathrm{HKLN}}+1,077_{\mathrm{PK}}$. Hasil uji-F variabel dependen dengan variabel independen diperoleh nilai Fcari=3,605 sedangkan Ftabel=3,41. Hasil Uji-t menunjukkan nilai tukar mata uang Dollar terhadap Rupiah $\mathrm{t}_{\text {cari }}=2,622$ sedangkan $\mathrm{t}_{\text {tabel }}=2,160$ dimana $\mathrm{H}_{\mathrm{a}}$ ditolak $\mathrm{H}_{0}$ diterima artinya nilai tukar mata uang Dollar terhadap Rupiah berpengaruh nyata terhadap volume ekspor kopi di Aceh. Hasil analisis terhadap harga kopi dalam negeri $\mathrm{t}_{\text {cari }}=2,348$ sedangkan $\mathrm{t}_{\text {tabel }}=2,160$ artinya harga kopi dalam negeri berpengaruh secara nyata terhadap volume ekspor kopi di Aceh. Hasil analisis terhadap harga kopi luar negeri $t_{\text {cari }}=-3,543$ sedangkan $\mathrm{t}_{\text {tabel }}=2,160$ artinya harga kopi di luar negeri berpengaruh secara nyata terhadap volume ekspor kopi di Aceh. Hasil analisis terhadap produksi kopi $\mathrm{t}_{\text {cari }}=1,313$ sedangkan $\mathrm{t}_{\text {tabel }}=2,160$ dimana $\mathrm{H}_{\mathrm{a}}$ diterima dan $\mathrm{H}_{0}$ ditolak artinya produksi kopi tidak berpengaruh secara nyata terhadap volume ekspor kopi di Aceh. Nilai koefisien determinasi $\left(\mathrm{R}^{2}\right)$ menunjukkan bahwa 54,6\% ekspor kopi di Aceh dipengaruhi oleh nilai tukar, harga kopi dalam negeri, harga kopi luar negeri dan produksi kopi sedangkan sisanya sebesar 45,4\% dipengaruhi faktor-faktor lain.
\end{abstract}

Kata kunci : Ekspor Kopi, Nilai Tukar, Harga Kopi Dalam Negeri, Harga Kopi Luar Negeri, dan Produksi Kopi

\begin{abstract}
This study aims to look at the factors that influence coffee exports in Aceh. The data source used is secondary data in the form of time series from $2001-2017$. The analysis model used is multiple linear regression, $\mathrm{F}_{\text {test }}, \mathrm{t}_{\text {test }}$, and $\mathrm{R}^{2}$ test. Regression analysis results obtained $\mathrm{Y}=-9,365-2,825_{\mathrm{NT}}+2,616_{\mathrm{HKDN}}-1,734_{\mathrm{HKLN}}+1,077_{\mathrm{PK}}$. F-test results for the dependent variable with the independent variable obtained $\mathrm{F}_{\text {test }}=3.605$ while $\mathrm{F}_{\text {table }}=3.41$. The $t_{\text {test }}$ results show the exchange rate of the Dollar against Rupiah $t_{\text {test }}=2.622$ while $t_{\text {table }}$ $=2.160$ where $\mathrm{H}_{\mathrm{a}}$ is rejected and $\mathrm{H}_{0}$ is accepted meaning the exchange rate of the Dollar against Rupiah has a significant effect on the volume of coffee exports in Aceh. The results of an analysis of the domestic coffee price $t_{\text {test }}=2,348$ while $t_{\text {table }}=2,160$ means that the domestic coffee price significantly affects the volume of coffee exports in Aceh. The results of an analysis of overseas coffee prices $t_{\text {test }}=-3.543$ while $t_{\text {table }}=2.160$ means that the price of coffee abroad has a significant effect on the volume of coffee exports in Aceh. The results of the analysis of coffee production $t_{\text {test }}=1,313$ while $t_{\text {table }}=2.160$ where $H_{a}$ is accepted and $\mathrm{H}_{0}$ is rejected, meaning that coffee production has no significant effect on the volume of coffee exports in Aceh. The coefficient of determination (R2) shows that 54.6\% of coffee exports in Aceh are influenced by the exchange rate, domestic coffee prices, foreign coffee prices and coffee production while the remaining $45.4 \%$ is influenced by other factors.
\end{abstract}

Keywords: Coffee Exports, Exchange Rates, Domestic Coffee, Coffee, and Coffee Production 


\section{PENDAHULUAN}

Ekspor suatu negara memainkan peran penting dalam meningkatkan pertumbuhan ekonomi. Ekspor dapat menyuplai anggaran negara melalui pendapatan dan mata uang asing yang dapat digunakan untuk memperbaiki infrastruktur dan menciptakan iklim investasi yang menarik (Mohsen, 2015). Salah satu produk perkebunan yang menjadi andalan Indonesia adalah kopi. Menurut data statistik analisis komoditi ekspor 2011-2017 perkebunan kopi di Indonesia pada tahun 2011, 2012, 2015 dan 2017 menunjukkan peningkatan sebesar 27,37 persen, 20,21 persen, 15,41 persen dan 17,47 persen. Apabila dilihat dari sisi berat ekspor komoditas kopi mengalami peningkatan tertingkatan tertinggi pada tahun 2015 sebesar 30,51 persen dan beratnya mencapai 499,6 ribu ton. Pemerintah Indonesia menempatkan ekspor sebagai salah satu lokomotif pertumbuhan ekonomi Indonesia.

Provinsi Aceh merupakan salah satu provinsi di Indonesia yang memiliki potensi sumber daya alam dari sektor pertanian, perkebunan, kehutanan, perikanan dan kelautan. Untuk sektor perkebunan, komoditi kopi merupakan salah satu komoditi ekspor yang memberikan kontribusi dalam perolehan devisa negara dan merupakan salah satu unggulan Provinsi Aceh. Saat ini Provinsi Aceh tergolong salah satu daerah produsen kopi Arabika dan Robusta di Indonesia. Berikut ini adalah data luas lahan, ekspor kopi dan produksi kopi Aceh selama periode 12 tahun terakhir:

Tabel 1. Ekspor Kopi Aceh dan Produksi Kopi

\begin{tabular}{ccrrr}
\hline Tahun & $\begin{array}{c}\text { Ekspor } \\
\text { (ton/tahun) }\end{array}$ & $\begin{array}{c}\text { Pertumbuhan } \\
\text { Ekspor(\%) }\end{array}$ & $\begin{array}{c}\text { Produksi } \\
\text { (ton/tahun) }\end{array}$ & $\begin{array}{c}\text { Pertumbuhan } \\
\text { Produksi (\%) }\end{array}$ \\
\hline 2006 & 1627 & - & 37894 & - \\
2007 & 9496 & 4,83 & 46308 & 0,22 \\
2008 & 5558 & $-0,41$ & 47124 & 0,017 \\
2009 & 4084 & $-0,27$ & 50190 & 0,07 \\
2010 & 2805 & $-0,31$ & 47805 & $-0,05$ \\
2011 & 3248 & 0,15 & 53950 & 0,13 \\
2012 & 2204 & $-0,32$ & 54314 & 0,007 \\
2013 & 2662 & 0,21 & 48282 & $-0,11$ \\
2014 & 2560 & $-0,05$ & 44343 & $-0,08$ \\
2015 & 2195 & $-0,14$ & 47444 & 0,07 \\
2016 & 2515 & 0,14 & 65231 & 0,37 \\
2017 & 6539 & 1,6 & 68493 & 0,05 \\
\hline Sumber: Badan Pusat Statistik.dan Bank Indonesia, 2007-2018 & &
\end{tabular}

Berdasarkan Tabel 1 dapat dilihat ekspor kopi di Aceh cenderung mengalami penurunan. peningkatan terbesar terjadi pada tahun 2007 yaitu sebesar 4,83\% sedangkan penurunan terbesar terjadi pada tahun 2008 yaitu sebesar $0.41 \%$. Selanjutnya untuk produksi kopi Aceh cenderung mengalami peningkatan, hanya pada tahun 2010, 2013 dan 2014 yang masing-masing mengalami penurunan sebesar $0,05 \%, 0,11$ dan $0,08 \%$. Peningkatan produksi terbesar terjadi pada tahun 2016 yaitu sebesar $0,37 \%$. 
Ekspor komoditas kopi Aceh setiap tahun menigkat, di pihak lain dapat saja ekspor terjadi penurunan. Penurunan ekspor dapat disebabkan oleh dua faktor yaitu faktor domestik dan pasar internasional. Faktor domestik antara lain mencakup kapasitas produksi, harga di pasar domestik dan berbagai kebijakan domestik, sedangkan faktor pasar internasional mencakup harga di pasar internasional, nilai tukar dan sisi permintaan dari negara importir produk Indonesia (Lubis, 2013). Peningkatan ekspor dikarenakan pasar internasional menyukai kopi Aceh khususnya jenis Arabika dan Robusta yang diproduksi di daerah ataran tinggi seperti Aceh Tengah dan Bener Meriah (Wahyudin, 2018).

Komalasari (2009) menyatakan bahwa produksi yang meningkat akan berpengaruh positif terhadap penawaran ekspor, yaitu semakin banyak jumlah produksi maka akan semakin banyak penawaran akan ekspor yang mana meningkatkan volume ekspor, dan sebaliknya semakin sedikit produksi kopi maka akan semakin sedikit pula penawaran akan ekspor sehingga menyebabkan volume ekspor menjadi menurun. Berdasarkan data Badan Pusat Statistik Aceh, volume ekspor kopi cenderung berfluktuatif setiap tahunnya. Terdapat beberapa tahun yang bertentangan dengan konsep tersebut, dimana pada tahun-tahun tersebut peningkatan produksi tidak diikuti oleh peningkatan ekspor. Melihat hal tersebut, kenaikan dan penurunan ekspor kopi tentunya dipengaruhi oleh beberapa faktor lain selain produksi. Hal inilah yang mendasari perlunya dilakukan penelitian tentang "Faktor-Faktor Yang Mempengaruhi Ekspor Kopi di Aceh".

\section{METODE PENELITIAN}

\section{Tempat dan Waktu Penelitian}

Penelitian dilakukan di Aceh, dengan pertimbangan bahwa Provinsi Aceh merupakan penghasil dan pengekspor kopi Arabika dan Robusta. Penelitian yang berjudul "Faktor-Faktor Yang Mempengaruhi Ekspor Kopi di Aceh" ini dilakukan pada tahun 2019.

\section{Objek dan Ruang Lingkup Penelitian}

Objek didalam penelitian ini adalah kopi di Aceh. Ruang lingkup penelitian terbatas pada informasi mengenai faktor-faktor yang mempengaruhi ekspor kopi di Aceh.

\section{Jenis dan Sumber Data}

Jenis data yang digunakan dalam penelitian ini adalah data sekunder yang berupa data runtut waktu (time series) dari tahun 2001 - 2017. Data tersebut diperoleh dari beberapa sumber dengan cara mengambil data-data statistik yang telah ada serta dokumen-dokumen lain yang terkait dan yang diperlukan. Dalam hal ini adalah Badan Pusat Statistik (BPS), Bank Indonesia (BI), World Bank, Dinas Perkebunan dan Pertanian, situs internet dan buku terkait. 


\section{Batasan Variabel}

Variabel-variabel yang digunakan dalam penelitian ini adalah ekspor kopi, nilai tukar, harga kopi dalam negeri, harga kopi luar negeri, dan produksi kopi.

\section{Model Analisis}

Mengingat data penelitian yang digunakan adalah sekunder, maka untuk memenuhi syarat maka perlu dilakukan pengujian atas beberapa asumsi klasik yang digunakan yaitu normalitas, multikolinieritas, autokolerasi, dan heteroskedastisitas. Adapun model analisis yang digunakan dalam penelitian ini adalah Regresi Linear Berganda yang teridiri dari uji $\mathrm{F}$, uji $\mathrm{t}$ dan uji koefisien determinasi $\left(\mathrm{R}^{2}\right)$. Analisis ini digunakan untuk melihat seberapa besar pengaruh variabel bebas yaitu : nilai tukar $\left(\mathrm{X}_{1}\right)$, harga kopi dalam negeri $\left(\mathrm{X}_{2}\right)$, harga kopi luar negeri $\left(\mathrm{X}_{3}\right)$, produksi kopi $\left(\mathrm{X}_{4}\right)$ terhadap variabel terikat yaitu ekspor kopi $(\mathrm{Y})$. Persamaan regresi linear berganda yaitu :

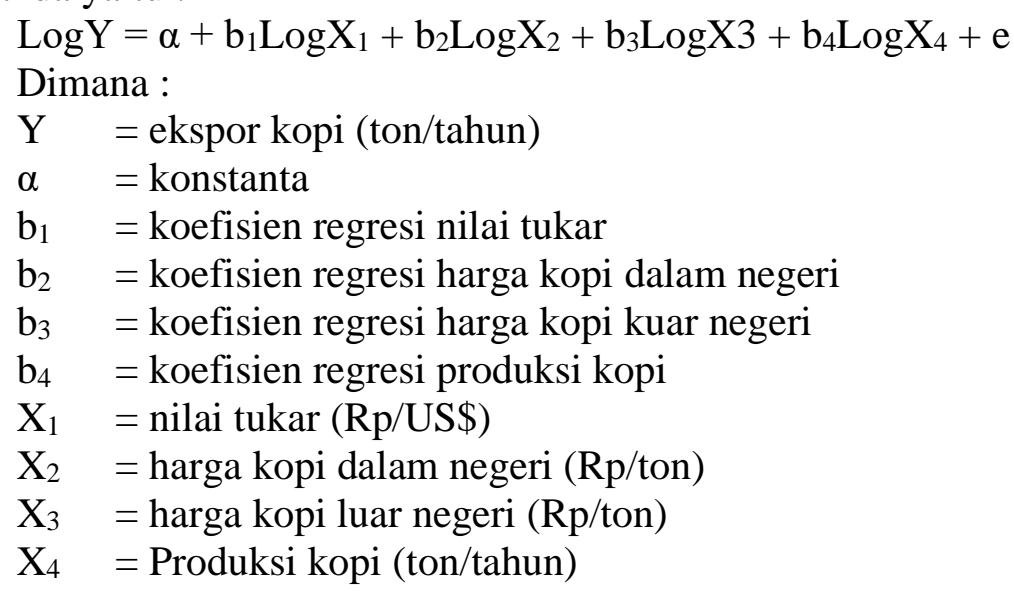

\section{HASIL PENELITIAN DAN PEMBAHASAN}

Adapun beberapa faktor yang mempengaruhi ekspor kopi Aceh yaitu nilai tukar, harga kopi dalam negeri, harga kopi luar negeri dan produksi kopi dalam negeri disajikan secara terpisah dengan menggunakan regresi linear berganda.

\section{Pengujian Asumsi Klasik}

a) Uji Normalitas

Uji normalitas pada penelitian ini menggunakan uji KolmogorovSmirnov yaitu dengan membandingkan data yang di uji normalitas dengan data yang telah ditransformasikan ke dalam bentuk Z-Score dan diasumsykan normal. Pada uji Kolmogorov-Smimov ini jika hasil pengujian dibawah 0,05 maka data dikatakan data tidak berdistribusi normal. Adapun hasil uji normalitas dapat dilihat pada Tabel 2.

Tabel 2. Hasil Uji Normalitas

\begin{tabular}{lcrrr}
\hline Model & Z & Asymp. Sig. (2-tailed) & Kriteria & \\
\hline Unstandardizers residual & 0,544 & 0,929 & 0,05 \\
\hline Sumber : Data Sekunder, 2020 (diolah) & & & &
\end{tabular}


Dari tabel diatas dapat dilihat bahwa p-value yaitu Asymp. Sig. (2-tailed) bernilai 0,929 dengan tingkat toleran sebesar 0,05 maka dapat disimpulkan bahwa data berdistribusi normal. Uji normalitas juga dapat dilihat dari grafik menggunakan Normal Probability Plot yang dapat dilihat pada Gambar di bawah ini :

\section{Normal P-P Plot of Regression Standardized Residual}

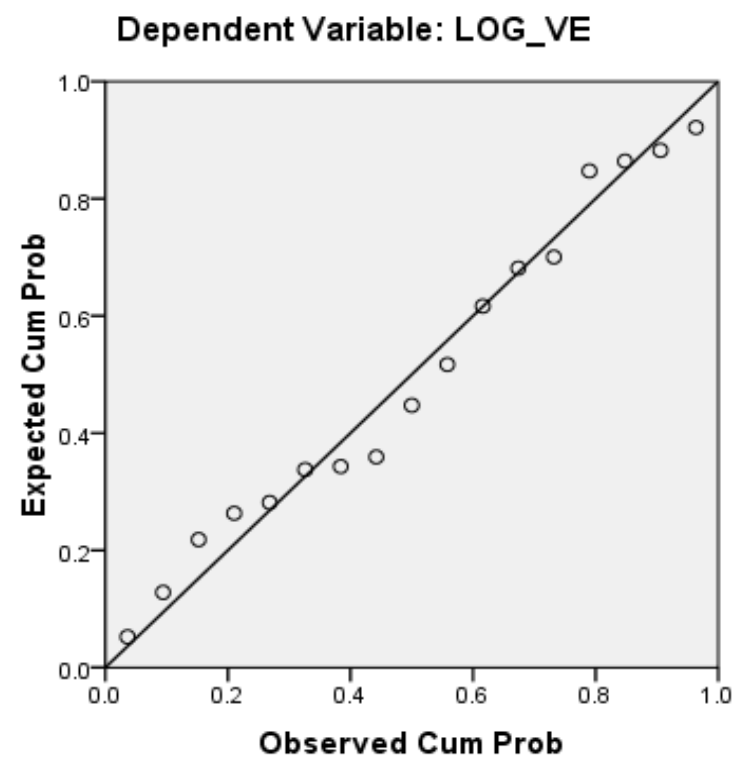

Gambar 1. Kurva Normal Probability Plot

\section{b) Uji Multikolineritas}

Multikolinieritas diuji dengan melihat nilai Variance Inflation Factor (VIF) dan nilai Tolerance (TOL) dari masing-masing variabel bebas terhadap variabel terikat. Bila $\mathrm{VIF}<10$ dan toreransinya $>0,05$ maka dapat dikatakan bahwa tidak terjadi multikolieritas. Hal ini dapat dilihat dari hasil uji Multikolieritas yang dapat dilihat pada tabel 3 .

Tabel 3. Hasil Uji Multikolieritas

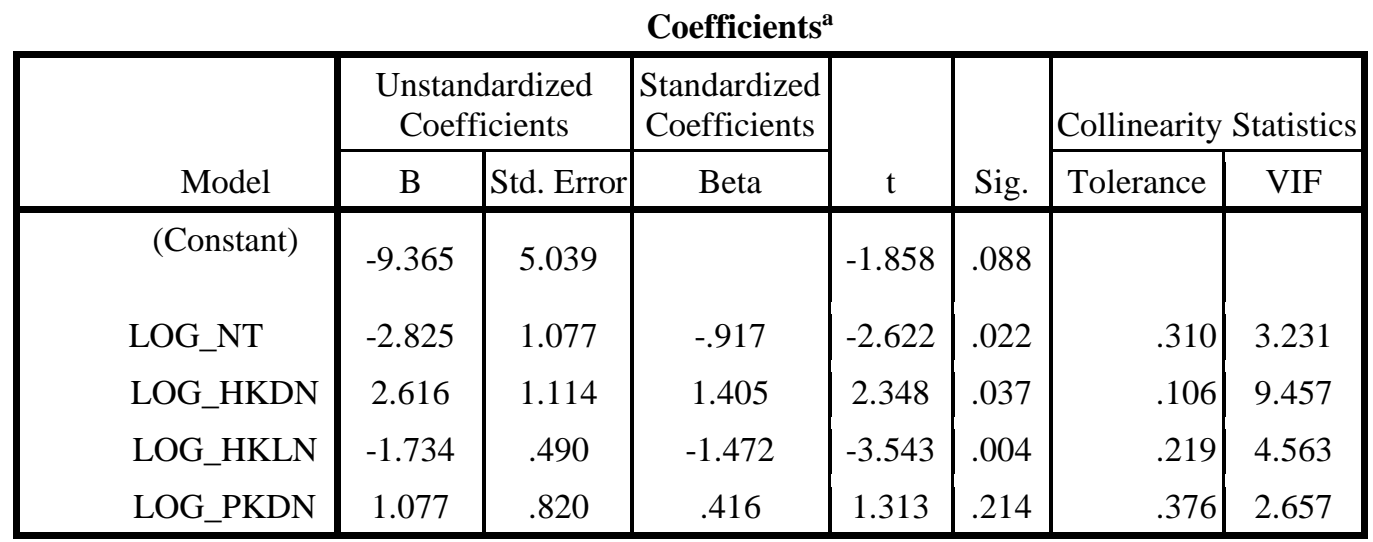

a. Dependent Variable: LOG_VE

Sumber: Data sekunder (diolah 2020) 
Dari tabel diatas diketahui nilai VIF dan toleran pada variabel nilai tukar, harga kopi dalam negeri, harga kopi luar negeri dan produksi kopi memiliki nilai lebih kecil dari VIF dan nilai toleran lebih besar maka dapat disimpulkan tidak terjadinya gejala multikolinieritas.

\section{c) Uji Heteroskedastisitas}

Heteroskedastisitas diuji dengan menggunakan metode Uji Glejser dengan melihat nilai signifikansi antara variabel independen dengan absolute residual. Adapun hasil uji heteroskedastisitas dapat dilihat pada tabel berikut ini:

Tabel 4 . Hasil Uji Heteroskedastisitas

\begin{tabular}{llcl}
\hline Variabel & Sig & & Kriteria \\
\hline Nilai tukar & 0,467 & & $>0,05$ \\
Produksi kopi Aceh & 0,520 & & \\
Harga kopi dalam negeri & 0,907 & \\
Harga kopi luar negeri & 0,943 & \\
\hline
\end{tabular}

Sumber: Data sekunder (diolah 2020)

Dari tabel diatas dapat diketahui bahwa pada model regres ini tidak terjadi gejala heteroskedastisitas. Hal ini disebabkan nilai signifikansi dari masing-masing variabel memiliki nilai yang lebih besar dari 0,05. Dengan demikian dapat disimpulkan bahwa model regresi tidak terdapat gejala heteroskedastisitas. Hasil uji heteroskedastisitas juga dapat dilihat dari grafik scatterplot yang dapat dilihat pada gambar berikut ini:

\section{Scatterplot}

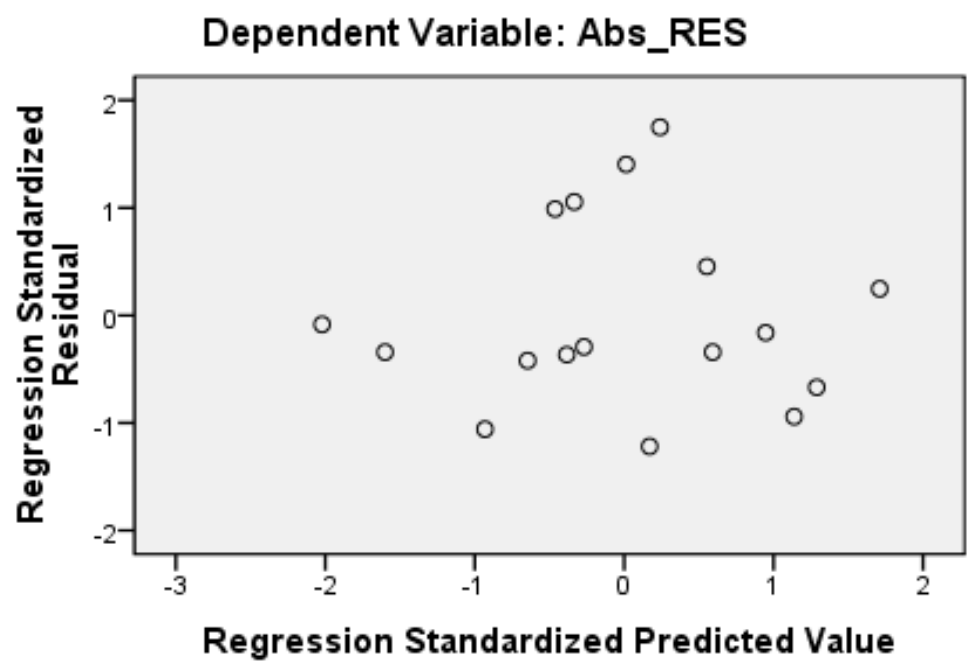

Gambar 2. Scatterplot

Berdasarkan Gambar 2 Scatterplot, dapat dilihat bahwa titik data menyebar secara acak dengan tidak membentuk pola tertentu serta tersebar di bawah angka 0 
pada sumbu Y. Hal ini berarti tidak terjadi gejala heteroskedasitas pada model regresi.

\section{d) Uji Autokorelasi}

Pengujian autokorelasi dilakukan untuk menguji suatu model apakah antara variabel penganggu masing-masing variabel bebas saling mempengaruhi. Adapun hasil pengujian autokorelasi dengan menggunakan uji run adalah sebagai berikut :

Tabel 5. Hasil uji autokorelasi

\begin{tabular}{|l|r|}
\hline & Unstandardized Residual \\
\hline Test Value ${ }^{\mathrm{a}}$ & \\
Cases < Test Value & -.02286 \\
Cases >= Test Value & 8 \\
Total Cases & 9 \\
Number of Runs & 17 \\
Z & 11 \\
Asymp. Sig. (2-tailed) & 0.518 \\
\hline
\end{tabular}

a. Median

Sumber: data sekunder (diolah 2020)

Dari hasil pengujian dengan menggunakan uji run test didapati nilai Asymp. Sig. $(2$-tailed $)=0,605$. Nilai residu menyebar secara acak sehingga tidak ada gejala autokorelasi.

\section{Hasil Analisis Regresi Linear Berganda}

Berikut adalah hasil analisis regresi linear berganda:

Tabel 6. Hasil Analisis Faktor-faktor yang Mempengaruhi Ekspor Kopi Aceh

\begin{tabular}{|c|c|c|c|}
\hline Model & $\begin{array}{l}\text { Unstandardized } \\
\text { Coefficient }\end{array}$ & $\mathrm{T}$ & Sig \\
\hline 1 constant & $-9,365$ & $-1,858$ & 0,088 \\
\hline$\left(\mathrm{X}_{1}\right)$ Nilai Tukar $(\mathrm{NT})$ & $-2,825$ & $-2,622$ & 0,022 \\
\hline$\left(\mathrm{X}_{2}\right)$ Harga Kopi Dalam Negeri (HKDN) & 2,616 & 2,348 & 0,037 \\
\hline$\left(\mathrm{X}_{3}\right)$ Harga Kopi Luar Negeri (HKLN) & $-1,734$ & $-3,543$ & 0,004 \\
\hline$\left(\mathrm{X}_{4}\right)$ Produksi Kopi & 1,077 & 1,313 & 0,214 \\
\hline \multicolumn{4}{|l|}{ F-cari $=3,605$} \\
\hline \multicolumn{4}{|l|}{ F-tabel = 341} \\
\hline \multicolumn{4}{|l|}{$\mathrm{T}$-tabel $=2,160$} \\
\hline $\mathrm{R}^{2}=0,548$ & & & \\
\hline
\end{tabular}

Sumber: lampiran 1 (diolah 2019)

Berdasarkan tabel itu maka dapat diambil persamaan regresi linier berganda sebagai berikut :

$$
\mathrm{Y}=-9,365-2,825_{\mathrm{NT}}+2,616_{\mathrm{HKDN}}-1,7_{3} 4_{\mathrm{HKLN}}+1,077_{\mathrm{PK}}
$$

Berdasarkan persamaan regresi yang diperoleh, maka variabel konstanta yang di dapatkan sebesar $-9,365$ yang berarti apabila nilai variabel harga kopi dalam negeri, harga kopi luar negeri, produksi kopi, permintaan kopi dan nilai tukar adalah 
konstan atau tetap maka volume ekspor kopi menurun sebanyak 9,365 ton per tahun.

Nilai koefisien nilai tukar mata uang Rupiah terhadap Dollar sebesar

2,825 menunjukkan bahwa terdapat pengaruh negatif antara volume ekspor kopi Aceh dengan nilai tukar mata uang Rupiah terhadap Dollar. Di mana setiap kenaikan nilai mata uang Rupiah terhadap Dollar sebesar Rp.1,- maka akan menurunkan volume ekspor kopi sebesar 2,825 ton dengan asumsi variabel lain tidak berubah (tetap). Apabila terjadi depresiasi nilai tukar maka akan meningkatkan permintaan ekspor sedangkan apabila terjadi apresiasi nilai tukar Rupiah terhadap Dollar maka akan menurunkan ekspor. Hasil yang diperoleh dalam penelitian yang dilakukan oleh Ginting (2013) menunjukkan bahwa terjadinya apresiasi nilai tukar akan menurunkan ekspor Indonesia. Begitu pula hal nya dengan komoditi kopi Aceh yang akan mengalami penurunan ekspor apabila terjadinya apresiasi nilai tukar. Ginting juga mengatakan penurunan ekspor diakibatkan oleh nilai tukar yang tidak berada pada level yang tepat.

Nilai koefisien regresi harga kopi dalam negeri yang dihasilkan adalah sebesar 2,616, hal ini menunjukkan bahwa jika harga kopi dalam negeri meningkat sebesar 1000 rupiah per ton maka akan meningkatkan volume ekspor kopi sebesar 2,616 ton per tahun dengan asumsi variabel lain tidak berubah (tetap). Ini sejalan dengan penelitian yang dilakukan Aprilla et.al (2012) yang mana diperoleh hasil bahwa harga kopi dalam negeri berpengaruh nyata terhadap kopi Indonesia. Hal ini terjadi disebabkan karena pengekspor kopi Indonesia tetap melakukan ekspor meskipun harga di pasar ekspor mengalami penurunan. Hal lain juga dikarenakan respon perubahan harga kopi di pasar ekspor terhadap harga kopi dalam negeri relatif lamban. Ketika harga kopi dalam negeri naik, produsen kopi cenderung meningkatkan penawaran ke dalam negeri karena dianggap naiknya harga dapat memberikan keuntungan lebih. Namun selisih antara harga luar negeri dan dalam negeri yang besar serta surplus produksi yang tinggi membuat produsen juga tidak dapat mengurangi ekspor. Hal ini juga berlaku pada komoditi kopi di Aceh, di mana dari tahun ke tahun harga kopi di Aceh terus mengalami peningkatan. Peningkatan harga kopi ini menunjukkan perkembangan mutu kopi yang ada di Aceh semakin meningkat dan semakin banyak digemari. Peningkatan harga ini tentunya memberikan keuntungan lebih bagi para produsen kopi di Aceh walaupun hanya mengandalkan pasar dalam negeri. Namun dengan produksi kopi yang mengalami surplus, mendorong produsen kopi di Aceh untuk tetap melakukan ekspor sehingga walaupun harga kopi di dalam negeri lebih tinggi dibandingkan harga luar negeri produsen kopi di Aceh tetap melakukan ekspor.

Nilai koefisien harga kopi luar negeri -1,734 menunjukkan bahwa terdapat pengaruh negatif antara volume ekspor kopi terhadap harga kopi luar negeri. Setiap kenaikan harga kopi luar negeri sebesar 1000 rupiah maka akan menurunkan volume ekspor kopi sebesar 1,734 ton dengan asumsi variabel lain tidak berubah (tetap). Hasil penelitian ini sesuai dengan penelitian yang dilakukan oleh (Widiyanti, S. 2009) di mana harga kopi luar negeri berpengaruh terhadap ekspor. Ini menunjukkan bahwa ekspor kopi Indonesia sangat peka terhadap ransangan harga, artinya apabila ada goncangan harga maka akan sangat mempengaruhi jumlah ekspor kopi yang diekspor. Tanda koefisien ini menunjukkan bahwa kopi 
adalah barang kebutuhan pokok yang permintaannya umumnya inelastik dimana perubahan permintaan (dalam persentase) lebih kecil dari perubahan harga.

Nilai koefisien regresi produksi kopi Aceh adalah sebesar 1,077 di mana setiap kenaikan produksi kopi Aceh sebesar 1 ton maka akan menaikkan volume ekspor kopi Aceh sebesar 1,077 ton dengan asumsi variabel lain tidak berubah. Kedua variabel ini menunjukkan pengaruh yang positif. Jika produksi kopi meningkat maka volume ekspor juga akan meningkat. Hal ini serupa dengan penelitian yang dilakukan oleh Densky. $\mathrm{R}$ et.al dimana perhitungan diperoleh nilai t-hitung 0.963637 dengan probabilitas $0,963637>\alpha=0,1$. Dengan kata lain secara parsial produksi kopi tidak berpengaruh signifikan terhadap ekspor kopi Indonesia periode 2000-2015.

\section{Uji Koefisien Determinasi $\left(\mathbf{R}^{2}\right)$}

Hasil uji koefisien determinasi $\left(\mathrm{R}^{2}\right)$, diperoleh nilai sebesar 0,546 . Angka tersebut akan diubah kedalam bentuk presentase yang artinya bahwa hubungan antara variabel yang dipengaruhi dan variabel yang mempengaruhi ekspor kopi Aceh adalah 54,6\% yang dapat dijelaskan oleh lima variabel yang mempengaruhi di dalam model persamaan ini. Sisanya $(45,4 \%)$ dijelaskan oleh faktor-faktor lain di luar persamaan ini.

\section{Uji Serempak}

Berdasarkan analisis regresi, diketahui hasil pengujian secara serempak (uji-F) antara variabel dipengaruhi dengan variabel yang mempengaruhi di peroleh nilai Fcari $=3,605$ sedangkan $\mathrm{F}$ tabel $=3,41$ di mana $\mathrm{H}_{0}$ ditolak dan $\mathrm{H}_{\mathrm{a}}$ diterima. Dengan demikian variabel nilai tukar, harga kopi dalam negeri, harga kopi luar negeri dan produksi kopi, secara serempak memiliki pengaruh secara nyata terhadap ekspor kopi Aceh.

\section{Uji t (Uji Parsial)}

a) Nilai Tukar

Secara uji-t statistik, hasil analisis nilai tukar mata uang Dollar terhadap Rupiah t-cari $=2,622$ sedangkan $\mathrm{t}$-tabel $=2,160$ dengan ketentuan $\mathrm{t}$-cari $>\mathrm{t}$-tabel pada tingkat kepercayaan $0,05 \%$ dimana $\mathrm{H}_{\mathrm{a}}$ ditolak dan $\mathrm{H}_{0}$ diterima yang maknanya secara parsial nilai tukar mata uang Dollar terhadap Rupiah berpengaruh nyata terhadap volume ekspor kopi di Aceh.

\section{b) Harga Kopi Dalam Negeri}

Secara uji-t statistik, hasil analisis terhadap harga kopi dalam negeri tcari $=2,348$ sedangkan $\mathrm{t}$-tabel $=2,160$ dengan ketentuan $\mathrm{t}$-cari $>\mathrm{t}$-tabel pada tingkat kepercayaan $0,05 \%$ dimana $\mathrm{H}_{\mathrm{a}}$ diterima dan $\mathrm{H}_{0}$ ditolak yang artinya secara statistik harga kopi dalam negeri berpengaruh secara nyata terhadap volume ekspor kopi di Aceh.

\section{c) Harga Kopi Luar Negeri}

Secara uji-t statistik, hasil analisis terhadap harga kopi luar negeri t-cari = 3,543 sedangkan t-tabel $=2,160$ dengan ketentuan $\mathrm{t}$-cari $>\mathrm{t}$-tabel pada tingkat 
kepercayaan $10 \%$ dimana $\mathrm{H}_{\mathrm{a}}$ ditolak dan $\mathrm{H}_{0}$ diterima yang artinya secara statistik harga kopi di luar negeri berpengaruh secara nyata terhadap volume ekspor kopi di Aceh.

\section{d) Produksi Kopi Aceh}

Secara uji-t statistik, hasil analisis terhadap produksi kopi $\mathrm{t}$-cari $=1,313$ sedangkan $\mathrm{t}$-tabel $=2,160$ dengan ketentuan $\mathrm{t}$-cari $<\mathrm{t}$-tabel pada tingkat kepercayaan $0,05 \%$ dimana $\mathrm{H}_{\mathrm{a}}$ diterima dan $\mathrm{H}_{0}$ ditolak yang artinya secara statistik produksi kopi tidak berpengaruh secara nyata terhadap volume ekspor kopi di Aceh.

\section{Simpulan}

\section{SIMPULAN DAN SARAN}

Berdasarkan hasil penelitian yang telah dilakukan mengenai faktor-faktor yang mempengaruhi ekspor kopi di Aceh, maka dapat disimpulkan bahwa nilai tukar, harga kopi dalam negeri dan harga kopi luar negeri berpengaruh secara nyata terhadap ekspor kopi di Aceh, sedangkan produksi kopi tidak berpengaruh secara nyata terhadap ekspor kopi di Aceh.

\section{Saran}

1. Hasil penelitian yang menunjukkan bahwa jumlah produksi kopi yang tidak berpengaruh terhadap ekspor kopi mengindikasi bahwa kopi Aceh memiliki posisi tersendiri di hati para pengekspor oleh karenanya kopi Aceh harus senantiasa menjaga mutu dan kualitas produknya agar tidak disaingi oleh kopi-kopi lain yang senantiasa berkembang.

2. Hasil penelitian yang menunjukkan bahwa nilai tukar, harga kopi dalam dan luar negeri yang berpengaruh terhadap ekspor mengidentifikasi bahwa keberadaan kopi di dalam negeri cukup baik sehingga peningkatan produksi kopi Aceh perlu ditingkatkan agar tidak hanya digunakan untuk memenuhi permintaan ekspor namun juga permintaan di dalam negeri.

\section{DAFTAR PUSTAKA}

Aprillia, S, Kutit Sukiyono dan M. Mustopa Romdhon. 2012. Efek Instabilasi Nilai Tukar Rupiah Terhadap Penawaran Ekspor Kopi Indonesia Dan Harga Kopi Domestik. Jurnal AGRISEP. Vol. 11 No.1.

Densky Reyandi, Syaparuddin \& Siti Aminah. 2018. Ekspor Kopi Indonesia Dan Faktor-Faktor Yang Mempengaruhinya. Jurnal Perdagangan, Industri \& Moneter. Vol. 6 No. 1.

Ginting Mulianti, A. 2013. Pengaruh Nilai Tukar Terhadap Ekspor Indonesia. Jurnal Buletin Ilmiah Litbang Perdagangan. Vol. 7 No. 1.

Komalasari, Aida. 2009. Analisis tentang Pelaksanaan Plant Layout Dalam Usaha Meningkatkan Efisiensi Produksi. Universitas Widyatama. Bandung. 
Lubis, Adrian D. 2013. Analisis Faktor yang Mempengaruhi Kinerja Ekspor Indonesia. Jurnal Penelitian pada Pusat Penelitian dan Pengembangan Perdagangan Luar Negeri. Jakarta.

Mohsen, Adel Shakeeb. 2015. Effect of Exports and Invesment on The Economic Grow in Syria. Internasional Journal of Management, accounting, and economics. Vol. 2 No. 6.

Simanjuntak, Parel Tua, Halomoan, Zainul Arifin dan Muhammad Kholid Mawardi. Pengaruh Produksi, Harga Internasional dan Nilai Tukar Rupiah Terhadap Volume Ekspor Rumput Laut Indonesia. Jurnal Administrasi Bisnis. Vol. 50 No. 3. Universitas Brawijaya. Malang.

Wahyudin. 2018. Ekspor Kopi Aceh. Kepala Badan Pusat Statistik Aceh. Aceh.

Sri Widiyanti, S. M. Kiptiyah, M. Iksan Semaoen. 2009. Analisis Ekspor Kopi Indonesia. Jurnal WACANA. Vol.12 No.1. 